\title{
BMJ Open Survival analysis of time to uptake of modern contraceptives among sexually active women of reproductive age in Nigeria
}

\author{
Adeniyi Francis Fagbamigbe, ${ }^{1,2}$ Ayo Stephen Adebowale, ${ }^{1}$ \\ ImranOludare Morhason-Bello ${ }^{3}$
}

To cite: Fagbamigbe AF, Adebowale AS, MorhasonBello IO. Survival analysis of time to uptake of modern contraceptives among sexually active women of reproductive age in Nigeria. BMJ Open 2015;5:e008371. doi:10.1136/bmjopen-2015008371

- Prepublication history for this paper is available online. To view these files please visit the journal online (http://dx.doi.org/10.1136/ bmjopen-2015-008371).

Received 1 April 2015 Revised 28 September 2015 Accepted 16 October 2015

CrossMark

${ }^{1}$ Department of Epidemiology and Medical Statistics, Faculty of Public Health, College of Medicine, University of Ibadan, Ibadan, Nigeria

${ }^{2}$ Faculty of Human and Social Sciences (HSS), School of Research and Postgraduate Studies (SoRPS), North West University, Mafikeng,

South Africa

${ }^{3}$ Department of Obstetrics and Gynaecology, Faculty of Clinical Sciences, College of Medicine, University of Ibadan/University College Hospital, Ibadan, Nigeria

Correspondence to Dr Adeniyi Francis

Fagbamigbe;

fadeniyi@cartafrica.org

\section{ABSTRACT}

Objective: To assess the timing of modern contraceptive uptake among married and never-married women in Nigeria.

Design: A retrospective cross-sectional study. Data and method: We used nationally representative 2013 Demographic and Health Survey data in Nigeria. Modern contraceptive uptake time was measured as the period between first sexual intercourse and first use of a modern contraceptive. Non-users of modern contraceptives were censored on the date of the survey. Kaplan-Meier survival curves were used to determine the rate of uptake. A Cox proportionalhazards model was used to determine variables influencing the uptake at $5 \%$ significance level.

Participants: A total of 33223 sexually active women of reproductive age.

Outcome measure: Time of uptake of a modern contraceptive after first sexual intercourse.

Results: The median modern contraceptive uptake time was 4 years in never-married and 14 years among ever-married women. Significant differences in modern contraceptive uptake existed in respondents' age, location, education and wealth status. Never-married women were about three times more likely to use a modern contraceptive than ever-married women (aHR=3.24 (95\% Cl 2.82 to 3.65)). Women with higher education were six times more likely to use a modern contraceptive than those without education (aHR=6.18 (95\% Cl 5.15 to 7.42$)$ ).

Conclusions: The rate of modern contraceptive uptake is low, and timing of contraceptive uptake during or after first sexual intercourse differed according to marital status. Age and number of children ever born influenced modern contraceptive uptake among the never-married women, but religion and place of residence were associated with the probability of modern contraceptive uptake among ever-married women.

\section{BACKGROUND}

Contraception is a cheap and effective strategy for promoting good reproductive health. ${ }^{1-3}$ This explains why governments and international agencies are making desperate

\section{Strengths and limitations of this study}

- Some of the strengths of our study are that we used a large nationally representative sample to assess duration between the time of first sexual activity and time of modern contraceptive uptake and focused on a global target population with high unmet need for family planning.

- We used survival analysis method to determine the time wasted before uptake of modern contraceptives although it is difficult to provide temporal evidence of explanatory factors considered in the Cox regression model since the data are cross-sectional.

- The same analysis could also be performed in other sub-Saharan African countries as this would provide an opportunity to compare policies and response to modern contraceptive uptake in the region.

- A limitation of our study is that we relied on recall of participants to determine the time of first sexual activity and modern contraceptive uptake and we did not use partners' data in the analysis.

- We used secondary data, which limits the choice of variables included the analysis.

efforts to ensure that people of childbearing age have unimpeded access to modern contraceptives. The predominantly high fertility rates in developing countries, ${ }^{4}$ especially in sub-Saharan Africa, are connected to low contraceptive use. ${ }^{25}$ The effect of high fertility on women and families is enormous. Apart from maternal depletion syndrome and its attendant problems, contraception also prevents unwanted pregnancies, thereby reducing the level of unsafe abortion and maternal mortality. The economic pressure of managing a large family, coupled with the overwhelming associated health complications, is a strong reason for implementing modern contraception in Nigeria. ${ }^{6}$ 
The maternal mortality ratio in Nigeria is 576 per 100000 live births. ${ }^{7}$ One in three women gives birth before age 20 and pregnancy-related morbidity and mortality rates are high among this group. One-quarter of the estimated 20 million unsafe abortions and 70000 abortion-related deaths each year occur among women aged 15-19 years. Similarly, the risk of dying during childbirth in women aged $<20$ years is twice that of those aged $\geq 20$ years. $^{8}$ An estimated 14 million unwanted pregnancies occur annually, with almost half in women aged 1524 years in sub-Saharan Africa. ${ }^{9}$ In addition, $16 \%$ of married women in Nigeria have an unmet need for family planning. ${ }^{7}$ This is slightly lower than the $20 \%$ reported in 2008. ${ }^{10}$ Modern contraception is one of the means of prevention of maternal deaths and might also prevent $90 \%$ of abortion-related morbidity and mortality. ${ }^{1}$

Nigeria, the most populous black nation has witnessed a sporadic increase in population growth in the past two decades. ${ }^{11}$ In 1990 , the population was slightly greater than 80 million and this has increased to 170 million in 2013. ${ }^{12}$ This high increase in population growth combined with low contraceptive use in Nigeria has prompted the Federal Government to institute policies at different times aimed at reducing the growth rate. For instance, the National Policy on Population for Development was launched in $1988^{13}$ and was revised in $2004 .{ }^{14}$ However, a review of the policy identified the low use of modern contraceptives as a barrier to its effectiveness. ${ }^{15}$ The reviewed policy was intended to overcome the shortcomings of the earlier policies and ensure an increase in contraceptive use nationwide.

Modern contraceptive uptake in the developing countries is generally lower than that in developed countries. ${ }^{16}$ Worldwide, the contraceptive use prevalence rate (CPR) is $56 \%$. The CPR in developed countries is $62 \%$ while it is $54 \%$ in less developed nations and $28 \%$ in the least developed nations. In Africa, the CPR is $26 \%$ and $20 \%$ in sub-Sahara Africa. Nigeria and neighbouring countries have a modern contraceptive use of about $10 \% .^{4}$ Nigeria has a total fertility rate of $5.6 \%$, the growth rate is $2.5 \%$ a year and the CPR is $<10.0 \% .^{711}$

Previous studies have identified sociodemographic differences in contraceptive use. Among factors identified in these studies are age at first sexual intercourse, religion, education, place of residence and economic status. $^{2} 5717$ The reproductive choices of young adults have also been found to have a great effect on their schooling, health and ultimately, transition to adulthood. ${ }^{18} 19$ In particular, early child bearing has been attributed to higher rates of maternal and child mortality, truncated education, larger family sizes, which, in turn, leads to an increase in population. ${ }^{20}$

Knowledge of family planning methods is $85 \%$, but the uptake is $<15 \%$. $^{721}$ The most common modern contraceptives used by women are the pill $(71 \%)$, injectables $(68 \%)$ and the male condom $(67 \%)$, whereas the male condom $(91 \%)$, the pill $(65 \%)$ and injectables $(60 \%)$ are the most common methods among men.
Although $15 \%$ of currently married women use some method of contraception, only $10 \%$ use a modern method of family planning. ${ }^{7}$ The reasons why a good knowledge of family planning methods has failed to translate to high uptake remain a great concern to government and researchers in Nigeria.

In Nigeria, national surveys have shown that the median age of first sexual intercourse is $<18$ years. ${ }^{7}{ }^{21}$ This is an age at which adolescents are most susceptible to sexually transmitted infections, including HIV/AIDS and human papillomavirus and other health complications. Unfortunately, in Nigeria, cultural beliefs prevent discussion among young people about reproduction, including the use of modern contraceptives. ${ }^{2}$ Young women who ask for contraceptives are regarded as promiscuous and as a result they choose either not to use them or to rely on their male sexual partners, who are likely to be older or their peers. ${ }^{21}$ Where such provisions are not available, young women have sex without the use of any contraception or make use of a traditional method, which is often not effective, ${ }^{3}$ leading to teenage pregnancy, early marriage or single parenthood. Owing to the shame attached to premarital pregnancy in Nigeria, unmarried women are expected to protect themselves from such embarassment. ${ }^{3}$ Equally, those who are married are expected to use modern contraceptives to guard against unwanted pregnancies in marriage. ${ }^{22} 23$ Thus, we argue that the timing of uptake of a modern contraceptive might be different among married women and those never married. This difference in the timing of contraceptive uptake according to marital status has not been adequately documented in Nigeria.

Many reports have been published on the prevalence of contraceptive use and the factors influencing it, ${ }^{3}{ }^{22-25}$ but there is little or no robust analysis on the time to uptake of modern contraceptives among sexually active women at the national level in Nigeria. This study was designed to determine the time it takes sexually active women in Nigeria to start using modern contraceptives after their first sexual experience and to identify factors influencing the uptake. It was considered that this information would be useful for effective family planning programming in Nigeria.

\section{METHODS}

We used the data collected during the 2013 Nigeria Demographic and Health Survey (NDHS). The sample was nationally representative and covered the entire population residing in non-institutional dwelling units in the country. The survey used the list of enumeration areas (EAs) prepared for the 2006 population census in Nigeria as a sampling frame. This was provided by the National Population Commission. The sample was designed to provide health indicator estimates nationally, zonally and for state populations. The sample design allowed for specific indicators to be calculated for each of the six zones, 36 states and the Federal Capital Territory, Abuja. 
Administratively, Nigeria is divided into 36 states and Federal Capital Territory (Abuja). Each state is subdivided into local government areas (LGAs) and each LGA is divided into localities. There are 774 LGAs in the country. In addition to these administrative units, during the 2006 population census, each locality was subdivided into census EAs. The primary sampling unit, referred to as a cluster in the 2013 NDHS, is defined on the basis of EAs from the 2006 EA census frame. The 2013 NDHS sample was selected using a stratified threestage cluster design consisting of 904 clusters-372 in urban areas and 532 in rural areas. A representative sample of 40680 households was selected for the survey, with a minimum target of 943 completed interviews for each state. A fixed sample of 45 households was selected for each cluster. All women aged 15-49 years, who were either permanent residents of the households in the 2013 NDHS sample or visitors present in the households on the night before the survey, were eligible and were interviewed. A total of 39902 women aged 15-49 years were identified as eligible for individual interviews and $98 \%$ of these were successfully interviewed. Of the 38948 respondents interviewed, 33223 (85.3\%) had had sex. Further analysis of modern contraceptive uptake was therefore based on the information provided by these respondents.

Among other questions, the women were asked about their background characteristics (age, religion, education, literacy, media exposure, etc), reproductive history and childhood mortality, knowledge, source and use of family planning methods. Time to uptake of a modern contraceptive since first sexual intercourse (sexual initiation) was used as dependent variable. Age, region, education, religion, residence, husbands' education, children ever born, wealth status and marital status are among the sociodemographic factors identified in previous studies as determinants of modern contraceptive use. ${ }^{2} 3517$ 22-25 The theoretical rationale for including these factors includes differentials in modern contraceptive availability by location (rural/urban) and geographical zones, affordability (wealth), knowledge (education), confidence to buy (age) etc. Details have been documented previously. ${ }^{3} 5172425$ The time to uptake of a modern contraceptive was computed as the time (years) difference of current age and age at first sexual intercourse for non-users and those censored accordingly. For respondents using modern contraceptives, the time to uptake of contraception was computed as the time difference between the year of uptake and age at sexual initiation. Women who had never had sexual intercourse were excluded from the study.

In view of the possibility of a woman starting to use a modern contraceptive before marriage and being married at the time of the survey, it would have been better to have used the 'time to uptake of modern contraceptives after marriage' as the response variable for married women. However, there is no variable in the dataset that we could have used to define 'time to uptake after marriage'. Nevertheless, we used alternatives that provided a reasonably approximate time to uptake of modern contraception among the married women. Time to modern contraceptive uptake was modelled using a discrete-time duration model. The survival time is assumed to begin at the time a woman has her first sexual intercourse until the time she starts using modern contraceptives. The survival time is censored for sexually active women who have never used a modern contraceptive at the time of the survey. The duration from first sexual intercourse to modern contraceptive uptake, ' $\mathrm{T}$ ', is assumed to be a discrete random variable that is always positive. The populations at risk are all sexually active women involved in the study. The observation continues until time ' $t$ ', at which the event of interest, uptake of a modern contraceptive, occurs or the time to the end of the study when observation is censored in 2013, the year of the survey, if the individual has not taken up modern contraceptive. The study ends for an individual at time ' $\mathrm{T}=\mathrm{t}$ ' if she has started using a modern contraceptive. Two quantitative terms were used in this study-namely, the survivor function $\mathrm{S}(\mathrm{t})$ and hazard function $h(t)$. The survivor function is the probability that a person survives longer than some specified time $\mathrm{t}$ without taking up a modern contraceptive, while the hazard function gives the instantaneous potential per unit of time for use of a modern contraceptive to be started, given that the individual modern contraceptive uptake time survived up to time t. Survival and hazard function are mathematically denoted by

$$
\mathrm{S}(\mathrm{t}(\mathrm{j}-1))=\Pi_{\mathrm{i}=1}^{\mathrm{j}-1} \mathrm{P}\left(\mathrm{T}>\mathrm{t}_{(\mathrm{i})} \mid \mathrm{T} \geq \mathrm{t}_{(\mathrm{i})}\right)
$$

and

$$
\mathrm{h}(\mathrm{t})=\frac{\mathrm{P}(\mathrm{t} \leq \mathrm{T}<\mathrm{t}+\Delta \mathrm{t} \mid \mathrm{T} \geq \mathrm{t})}{\Delta \mathrm{t}}
$$

respectively.

The Cox proportional-hazards model was used to predict the strength of the relationship between each of the selected independent variables and censored timing of modern contraceptive uptake. It

gives an expression for the hazard at time $t$ for an individual with a given specification of a set of independent variables denoted by ' $\mathrm{x}$ ', which are predictor variables that are being modelled to predict an individual's hazard. The Cox proportional-hazards regression assumes the relationship for one covariate where $h_{0}(t)$ is the baseline hazard function, $x_{i}$ are the covariates and $\beta_{i}$ are the coefficients.

$$
\mathrm{h}\left(\mathrm{t} ; \mathrm{x}_{\mathrm{i}}\right)=\mathrm{h}_{0}(\mathrm{t}) \exp \left(\mathrm{x} \beta_{i}\right)
$$

We also stratified Cox regression estimates. In the stratified estimator, the hazard at time $\mathrm{t}$ for a subject in group ' $\mathrm{i}$ ' is assumed to be

$$
\mathrm{h}_{\mathrm{i}}(\mathrm{t})=\mathrm{h}_{\mathrm{i} 0}(\mathrm{t}) \exp \left(\beta_{1} \mathrm{x}_{\mathrm{i} 1}+\cdots+\beta_{\mathrm{k}} \mathrm{x}_{\mathrm{ik}}\right)
$$


That is, the coefficients are assumed to be the same, regardless of group, but the baseline hazard can be group specific. In our stratified Cox analysis, we tested whether the proportional-hazards assumption was violated using the significance of the HRs and Wald $\chi^{2}$ statistics. Variables significant in the bivariate Cox regression were used in the multiple Cox regression to assess association with the outcome variable while controlling for confounders. Sampling weights were applied in our analysis. The weighting was based on the sampling fractions derived from the sample size and the total population of each state constituting Nigeria. Statistical significance was determined at $\mathrm{p}$ value $=0.05$. We used the Stata (V.13) statistical analysis software for the analysis.

\section{Ethical approval}

Ethical approval was sought from the Nigeria National Health Research ethics committee by the data originators and granted before starting the survey. Also, informed consent was received from the participants before interviewing them. We obtained the approval from Measure of DHS for permission to use the data before analysis.

\section{RESULTS}

Of the 38948 respondents, $33223(85.3 \%)$ had had sex. Mean age of sexual debut was 14.31 (95\% CI 14.24 to 14.38 ) years with a range of $8-46$ years. About threefifths $(57.9 \%)$ of the respondents were from rural areas, $37.8 \%$ had no education, $20.1 \%, 17.4 \%$ and $18.3 \%$ were aged 15-19, 20-24 and 25-29 years, respectively. Only $42.6 \%$ of respondents aged 15-19 years had had sex. Only $11.4 \%$ of the sexually active respondents were currently using a modern contraceptive. Highest use of a modern contraceptive was found among respondents aged $20-24$ years $(16.0 \%), 27.2 \%$ in the South West, $16.8 \%$ in urban areas, $26.5 \%$ among respondents with higher educational attainment, $18.7 \%$ among women in the richest wealth quintiles, $15.8 \%$ among never-married and $9.9 \%$ among ever-married women. The median year to uptake of modern contraceptive was 4 years, 14 years and 13 years among the never-married women, evermarried women and all sexually active women, respectively, as shown in table 1.

At the year of sexual initiation $79.4 \%$ of never-married women and $5.2 \%$ of ever-married women used a modern contraceptive; $40.6 \%$ versus $7.3 \%$ during the second year; and $34.4 \%$ versus $12.0 \%$ during the third year. The proportion fell among never-married women as the year from sexual initiation increased but it rose gently among ever-married women to its peak at about the 17th year of sexual activities where it remained the same as the overall proportion of modern contraceptive users among all women. Proportions using a modern contraceptive within each group were about the same between the 12th and 17th year of sexual activities (figure 1).

Over two-fifths $(41.5 \%)$ of the modern contraceptive users were currently using male condoms, $22.3 \%$ used injections, $17.2 \%$ were taking pills, $6.9 \%$ using an intrauterine device while $<1 \%$ each used female condoms, diaphragm, foam and male sterilisation (data not shown). In figure 2, we compared the rate of modern contraceptive uptake among sexually active women by marital status. The rate among the never-married women was higher than among ever-married women.

Figure 3 shows the probabilities of modern contraceptive uptake among the never-married women according to their sociodemographic characteristics. Examination of the results according to age showed that nevermarried women aged 20-24 years were more likely than other never-married women to adopt a modern contraceptive as the years of sexual activities progressed. Similarly, never-married women in urban areas and within the highest wealth quintiles had the highest probabilities of adopting a modern contraceptive.

In figure 4, the probabilities of modern contraceptive uptake among the ever-married women according to their sociodemographic characteristics are shown. Ever-married women in the South West region had the highest likelihood of taking up a modern contraceptive than ever-married women from other regions as their years of sexual activities progressed. Also, ever-married women who were either Catholics or practising another Christian faith had a higher probability of modern contraceptive uptake than other ever-married women as the years of sexual activity progressed.

The unadjusted HR showed that the chances of a never-married woman adopting a modern contraceptive reduced by $7 \%$ for every additional year after sexual initiation. Those aged $20-24$ years were $42 \%$ more likely to start using a modern contraceptive than never-married women aged $15-19$ years ( $\mathrm{HR}=1.42$ (95\% CI 1.14 to 1.77)). Never-married women from the North East were $31 \%$ times less likely to take up a modern contraceptive than their counterparts from North Central $(\mathrm{HR}=0.69$ (95\% CI 0.45 to 1.04)). According to wealth status, never-married women in the richest wealth quintile were more than twice as likely to take up a modern contraceptive than never-married women in the poorest wealth quintile, while those having secondary $(\mathrm{HR}=7.14(95 \%$ CI 2.67 to 19.11 ) or higher ( $\mathrm{HR}=7.88$ (95\% CI 2.93 to 21.16) education were over seven times more likely to take up a modern contraceptive than those without any formal education (table 2). Among the ever-married women, those from the South West were about $40 \%$ more likely to take up a modern contraceptive than those from the North Central (HR=1.42 (95\% CI 1.28 to 1.58) ) and those in the North East over $80 \%$ times less likely (HR=0.20 (95\% CI 0.17 to 0.24$)$ ).

In the multivariate analysis, the adjusted HR (aHR) shows that the proportion of never-married women aged 20-24 years to uptake was $31 \%$ higher than for never- 
Table 1 Distribution of respondents by sociodemographic characteristics, sexual activities, modern contraceptive use and median year to uptake of modern contraceptives

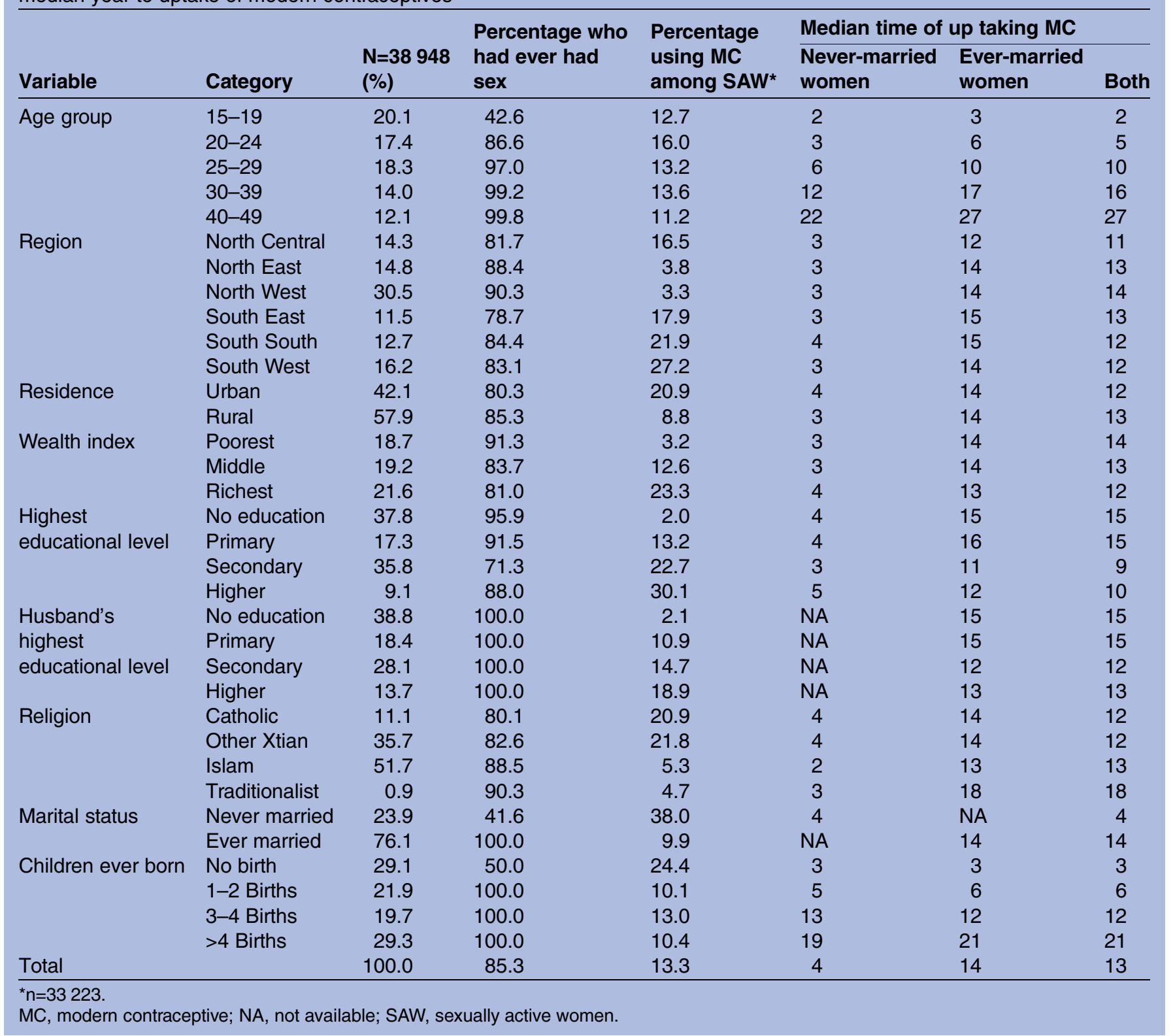

married woman aged 15-19 years $(\mathrm{aHR}=1.31 \quad(95 \%$ CI 1.05 to 1.63$)$ ), while never-married woman with one or two births were $22 \%$ times less likely to take up a modern contraceptive than those with no previous birth $(\mathrm{aHR}=0.78(95 \%$ CI 0.65 to 0.93$))$. Ever-married women who practised Islam were $42 \%$ times less likely to take up a modern contraceptive than their counterparts practising Catholic religion (aHR $=0.58 \quad(95 \%$ CI 0.49 to $0.67)$ ). After controlling for other variables, sexually active women with higher education in Nigeria were six times more likely to take up a modern contraceptive than those without any formal education $(\mathrm{aHR}=6.18$ (95\% CI 5.15 to 7.42$)$ ), and rural women were $17 \%$ less likely to take up a modern contraceptive than urban sexually active women $(\mathrm{aHR}=0.83(95 \%$ CI 0.76 to 0.90$)$ as shown in table 3 .

\section{DISCUSSION}

Modern contraceptives effectively prevent unplanned pregnancy and some associated health complications of unprotected sexual activity, such as HIV, human papillomavirus infection and sexually transmitted infections. ${ }^{26}$ Uptake of a modern contraceptive method is often measured and compared across different settings and is sometimes used as proxy indicator for the burden of unprotected sexual activity and unplanned pregnancy. ${ }^{27}$ In this study, the average national modern contraceptive uptake among sexually active women was $11.4 \%$. The uptake was highest among those aged 20-24 years, resident in the South West, living in an urban community and with the highest education and wealth quintiles. The shortest interval to uptake of modern contraception was 4 years after initiation of sexual activity and this was 
Figure 1 Proportions of sexually active women taking up modern contraceptive (MCs) by years of sexual activities and marital status.

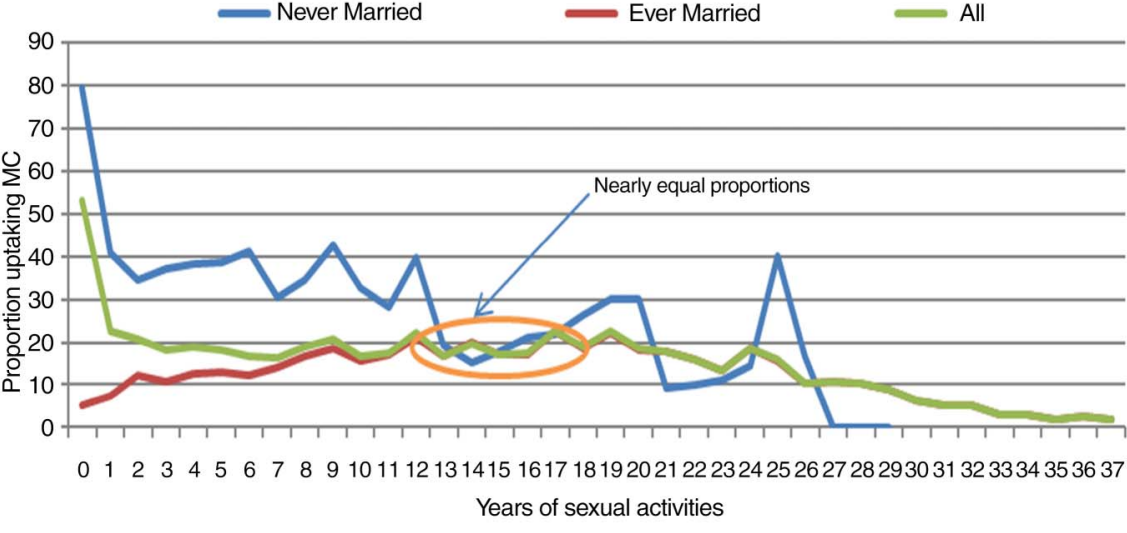

understandably among never-married women. This interval is more than three times shorter than for the ever-married women. The proportion of those using modern contraception each year from the point of sexual initiation fell steeply in the never-married women and thereafter, reached a plateau after 17 years. On the contrary, there was a steady rise among the ever married until 17 years after sexual initiation. Both groups, however, had a similar proportion of contraceptive uptake at 17 years after sexual initiation.

The generally low level of modern contraceptive uptake in Nigeria, especially among sexually active women, remains a source of concern. The average uptake is now marginally higher than recorded in the $2008 \mathrm{NDHS},{ }^{10}$ but this is not commensurate with the investment in family planning in the country during this period.$^{10}$ Unlike previously published articles on modern contraception in Nigeria, our analysis modelled the time interval between sexual initiation and uptake of contraception using nationally representative data.

The lessons derived are manifold. First, there is an average lag period of at least 4 years before sexually active women in Nigeria take up modern contraception, possibly owing to either a lack of awareness or access to contraceptive commodities and services. Second, factors such as regional variations, urban-rural divide, wealth indices and education, which have been associated with uptake of modern contraceptives, are still significant in this analysis. ${ }^{22} 2325$ The low contraceptive uptake in northern Nigeria is responsible for a comparatively greater upsurge in several family planning interventions in this region than in others. ${ }^{24}$ Despite this effort, southern regions still have a higher modern contraception uptake among the sexually active women. The known associated factors responsible for the poor uptake in northern Nigeria are education, sociocultural disposition and interpretation of modern contraception. ${ }^{28}{ }^{29}$ Some have argued that northern regions of the country still have a conservative approach towards modern contraceptive methods of family planning. ${ }^{28}$ This is reinforced by evidence of a higher awareness of family planning and use of traditional or unorthodox methods and high fertility rates among women in the north. ${ }^{24}$
Figure 2 Survival analysis of modern contraceptive uptake among all respondents by marital status.

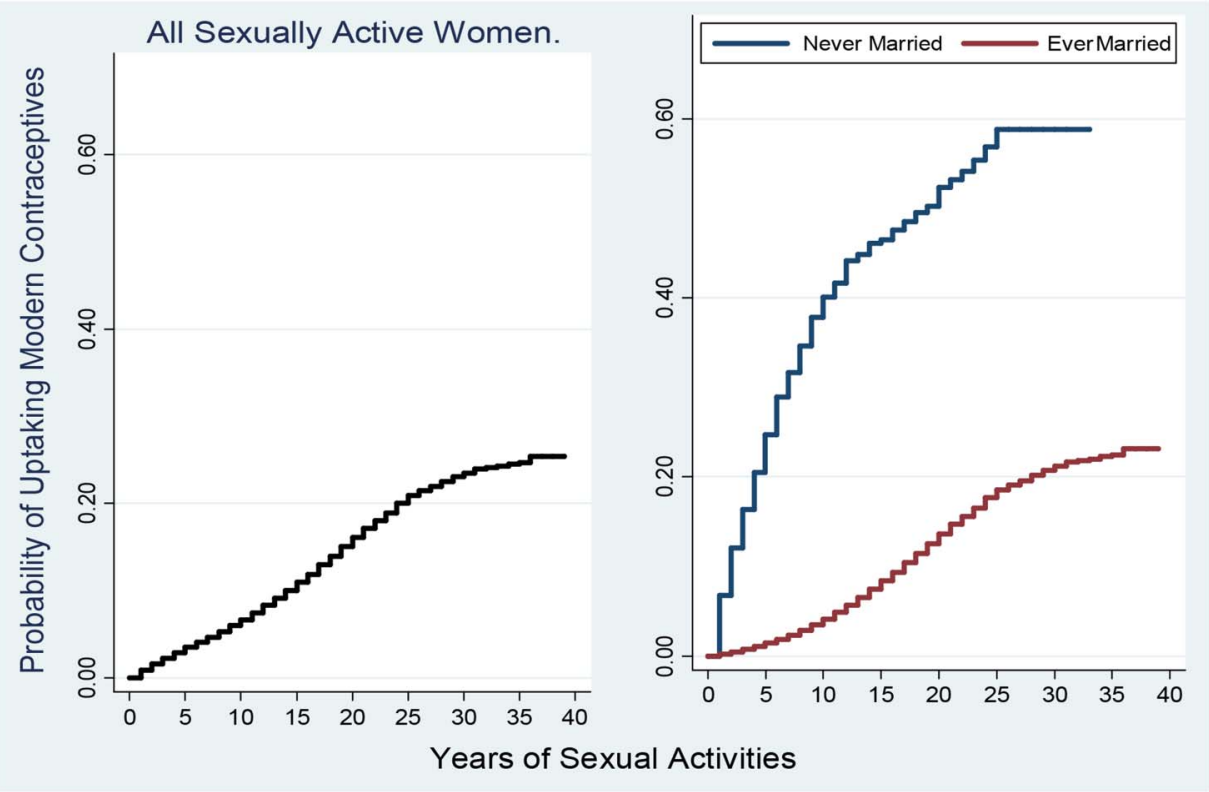



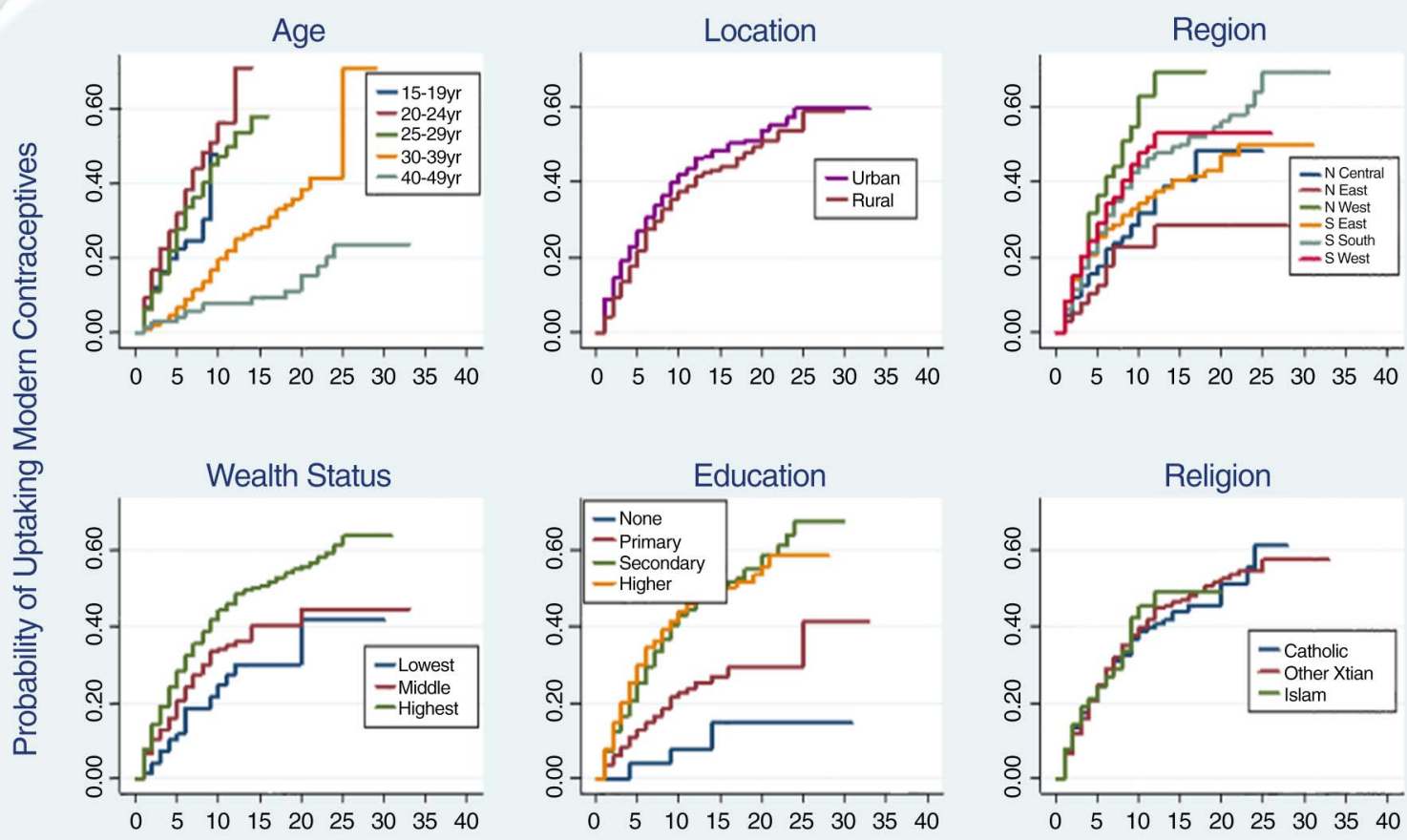

Years of Sexual Activities

Figure 3 Probabilities of modern contraceptive uptake among never-married women according to some selected sociodemographic characteristics.
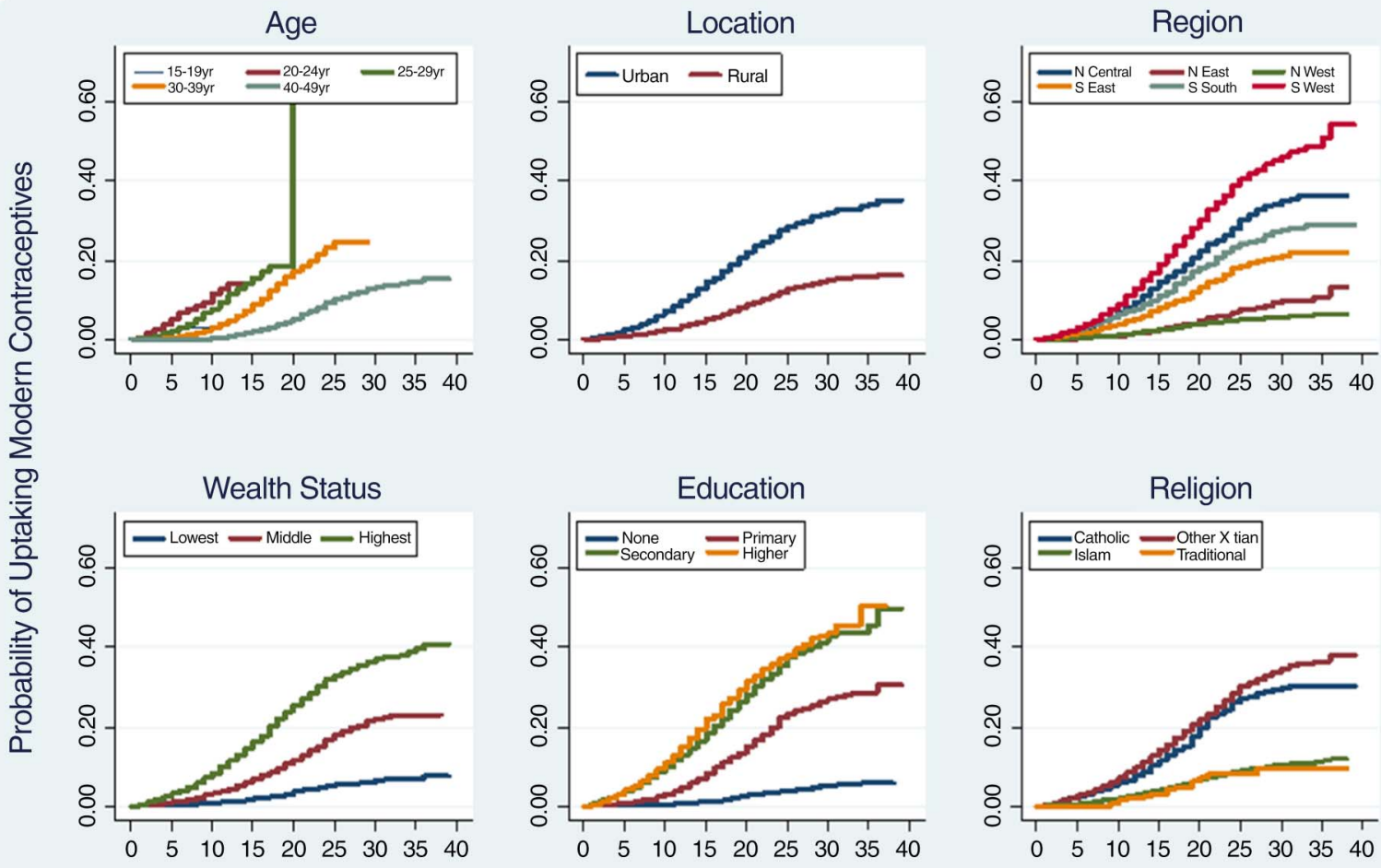

Years of Sexual Activities

Figure 4 Probabilities of modern contraceptive uptake among ever-married women according to selected sociodemographic characteristics. 
Table 2 Unadjusted determinants of modern contraceptive uptake among the women

\begin{tabular}{|c|c|c|c|c|}
\hline \multirow[b]{2}{*}{ Characteristics } & \multirow[b]{2}{*}{ Categories } & \multicolumn{3}{|c|}{ Unadjusted determinants of modern contraceptive uptake } \\
\hline & & $\begin{array}{l}\text { Never married } \\
\mathrm{HR}(95 \% \mathrm{Cl})\end{array}$ & $\begin{array}{l}\text { Ever married } \\
\text { HR }(95 \% \mathrm{Cl})\end{array}$ & $\begin{array}{l}\text { Both } \\
\text { HR }(95 \% \mathrm{Cl}) \\
\end{array}$ \\
\hline Marital status & $\begin{array}{l}\text { Never married } \\
\text { Ever married }\end{array}$ & & & $\begin{array}{l}10.1(9.2 \text { to } 11.0)^{\star} \\
\text { Reference }\end{array}$ \\
\hline Age (years) $\dagger$ & & $0.93(0.92 \text { to } 0.94)^{*}$ & $0.89(0.88 \text { to } 0.90)^{*}$ & $0.88(0.87 \text { to } 0.88)^{\star}$ \\
\hline \multirow[t]{5}{*}{ Age group } & $15-19$ & Reference & & \\
\hline & $20-24$ & $1.42(1.14 \text { to } 1.77)^{*}$ & $1.40(0.94$ to 2.10$)$ & $0.99(0.82$ to 1.20$)$ \\
\hline & $25-29$ & $1.08(0.86$ to 1.37$)$ & $0.68(0.45$ to 1.01$)$ & $0.46(0.38 \text { to } 0.55)^{\star}$ \\
\hline & 30-39 & $0.37(0.27 \text { to } 0.50)^{*}$ & $0.29(0.19 \text { to } 0.43)^{*}$ & $0.16(0.13 \text { to } 0.19)^{\star}$ \\
\hline & $40-49$ & $0.12(0.06 \text { to } 0.25)^{*}$ & $0.10(0.06 \text { to } 0.14)^{*}$ & $0.05(0.04 \text { to } 0.06)^{\star}$ \\
\hline \multirow[t]{6}{*}{ Region } & North Central & Reference & & \\
\hline & North East & $0.69(0.45$ to 1.04$)$ & $0.20(0.17 \text { to } 0.24)^{*}$ & $0.22(0.18 \text { to } 0.25)^{\star}$ \\
\hline & North West & $2.04(1.38 \text { to } 3.03)^{*}$ & $0.15(0.13 \text { to } 0.18)^{\star}$ & $0.16(0.14 \text { to } 0.19)^{\star}$ \\
\hline & South East & $1.22(0.94$ to 1.57$)$ & $0.56(0.49 \text { to } 0.65)^{*}$ & $0.80(0.70 \text { to } 0.90)^{*}$ \\
\hline & South South & $1.43(1.14 \text { to } 1.80)^{*}$ & $0.80(0.71 \text { to } 0.90)^{*}$ & $1.11(1.00 \text { to } 1.23)^{\star}$ \\
\hline & South West & $1.61(1.25 \text { to } 2.07)^{*}$ & $1.42(1.28 \text { to } 1.58)^{*}$ & 1.47 (1.34 to 1.62$)$ \\
\hline \multirow[t]{2}{*}{ Residence } & Urban & Reference & & \\
\hline & Rural & $0.80(0.69 \text { to } 0.92)^{*}$ & $0.38(0.35 \text { to } 0.41)^{*}$ & $0.39(0.37 \text { to } 0.42)^{*}$ \\
\hline \multirow[t]{3}{*}{ Wealth index } & Poorest & Reference & & \\
\hline & Middle & $1.7(1.23 \text { to } 2.35)^{*}$ & $3.69(3.19 \text { to } 4.28)^{*}$ & $4.00(3.50 \text { to } 4.57)^{\star}$ \\
\hline & Richest & $2.4(1.79 \text { to } 3.21)^{*}$ & $8.09(7.14 \text { to } 9.17)^{\star}$ & $8.52(7.60 \text { to } 9.56)^{*}$ \\
\hline \multirow[t]{4}{*}{ Highest education } & No education & Reference & & \\
\hline & Primary & $3.36(1.21 \text { to } 9.33)^{*}$ & $6.39(5.51 \text { to } 7.40)^{*}$ & $6.59(5.70 \text { to } 7.62)^{\star}$ \\
\hline & Secondary & $7.14(2.67 \text { to } 19.11)^{*}$ & $13.1(11.4 \text { to } 15.1)^{*}$ & $15.8(13.8 \text { to } 18.1)^{\star}$ \\
\hline & Higher & $7.88(2.93 \text { to } 21.16)^{*}$ & $14.4(12.3 \text { to } 16.8)^{*}$ & $18.9(16.3 \text { to } 21.9)^{*}$ \\
\hline \multirow[t]{4}{*}{ Religion } & Catholic & Reference & & \\
\hline & Other Xtian & $1.01(0.85$ to 1.21$)$ & $1.18(1.05 \text { to } 1.33)^{*}$ & $1.11(1.00 \text { to } 1.22)^{\star}$ \\
\hline & Islam & $1.09(0.81$ to 1.46$)$ & $0.31(0.28 \text { to } 0.36)^{*}$ & $0.25(0.22 \text { to } 0.28)^{\star}$ \\
\hline & Traditionalist & $0.96(0.13$ to 6.85$)$ & $0.28(0.16 \text { to } 0.48)^{*}$ & $0.23(0.14 \text { to } 0.38)^{\star}$ \\
\hline \multirow[t]{4}{*}{ Children ever born } & No birth & Reference & & \\
\hline & 1-2 Births & $0.73(0.61 \text { to } 0.86)^{*}$ & $5.48(3.80 \text { to } 7.91)^{*}$ & $0.47(0.42 \text { to } 0.52)^{\star}$ \\
\hline & 3-4 Births & $0.31(0.15 \text { to } 0.66)^{*}$ & $3.72(2.58 \text { to } 5.35)^{*}$ & $0.30(0.27 \text { to } 0.34)^{\star}$ \\
\hline & $>4$ Births & $0.15(0.02$ to 1.08$)$ & $1.43(0.99$ to 2.06$)$ & $0.13(0.11 \text { to } 0.14)^{\star}$ \\
\hline
\end{tabular}

Another interesting finding is that some factors that are associated with the probability of modern contraceptive uptake differed according to marital status. In the never-married category modern contraceptive uptake by women aged 20-24 years was 31\% more likely than in those who were younger, and in those who had already had one or two previous children was less likely than in those without children. This might suggest a differential preference and need as well as awareness about the implication of unprotected sexual activity among these groups of women. ${ }^{30}$ Elsewhere, young adults are often reported to engage in safer sexual activity than adolescents. ${ }^{31}$ Within the ever-married group in this study, religion and place of residence were associated with the probability of modern contraceptive uptake. Women of Catholic faith were more likely to use modern contraception than those who professed Islamic religion. This observation did not align with the widely known perception of Catholic worshipers and modern contraception. ${ }^{31} 32$ This will require further studies, especially social science research, which might provide better insight into the motivation among Catholics to use modern contraception, contrary to their doctrine.

It is fascinating that the proportions of those using modern contraception among the never-married and ever-married groups is the same at 17 years after sexual initiation. This despite each group having a different proportional trend from the point of sexual initiation. It might suggest that women at this particular time have similar reproductive and sexual intentions. The 17 th year within the reproductive span is probably above the average age for childbearing and also close to the perimenopausal age in Nigeria. ${ }^{33}$ This has technically removed the observed age difference of the respondents.

The observed 'lag period' in this analysis might indicate that access to modern contraceptives in the early reproductive life of women is poor. Incidentally, this period is also the age range of adolescent and young adults. Although, the Nigerian government has implemented several programmes, including family life education or sexuality education, to educate and promote 
Table 3 Adjusted determinants of modern contraceptive uptake among the women

\begin{tabular}{|c|c|c|c|c|}
\hline \multirow[b]{2}{*}{ Variable } & \multirow[b]{2}{*}{ Categories } & \multicolumn{3}{|c|}{ Adjusted determinants of modern contraceptive uptake } \\
\hline & & $\begin{array}{l}\text { Never married } \\
\text { HR }(95 \% \mathrm{Cl})\end{array}$ & $\begin{array}{l}\text { Ever married } \\
\mathrm{HR}(95 \% \mathrm{Cl})\end{array}$ & $\begin{array}{l}\text { Both } \\
\text { HR }(95 \% \mathrm{Cl})\end{array}$ \\
\hline Marital status & $\begin{array}{l}\text { Never married } \\
\text { Ever married }\end{array}$ & & & $\begin{array}{l}3.21(2.82 \text { to } 3.64)^{*} \\
\text { Reference }\end{array}$ \\
\hline Age (years)† & & $0.91(0.89 \text { to } 0.92)^{*}$ & $0.84(0.83 \text { to } 0.85)^{\star}$ & $0.84(0.83 \text { to } 0.85)^{*}$ \\
\hline \multirow[t]{5}{*}{ Age group } & $15-19$ & Reference & & \\
\hline & $20-24$ & $1.31(1.05 \text { to } 1.63)^{*}$ & $0.75(0.50$ to 1.12$)$ & $0.94(0.78$ to 1.14$)$ \\
\hline & $25-29$ & $0.89(0.70$ to 1.14$)$ & $0.26(0.17 \text { to } 0.38)^{\star}$ & $0.38(0.31 \text { to } 0.46)^{*}$ \\
\hline & 30-39 & $0.28(0.20 \text { to } 0.39)^{*}$ & $0.08(0.05 \text { to } 0.12)^{\star}$ & $0.11(0.09 \text { to } 0.13)^{*}$ \\
\hline & $40-49$ & $0.10(0.05 \text { to } 0.20)^{*}$ & $0.02(0.01 \text { to } 0.03)^{\star}$ & $0.03(0.02 \text { to } 0.04)^{*}$ \\
\hline \multirow[t]{6}{*}{ Region } & North Central & Reference & & \\
\hline & North East & $0.86(0.56$ to 1.31$)$ & $0.41(0.34 \text { to } 0.49)^{\star}$ & $0.46(0.39 \text { to } 0.54)^{*}$ \\
\hline & North West & $2.49(1.67 \text { to } 3.71)^{*}$ & $0.4(0.33 \text { to } 0.47)^{\star}$ & $0.47(0.40 \text { to } 0.55)^{\star}$ \\
\hline & South East & $1.47(1.12 \text { to } 1.92)^{*}$ & $0.39(0.34 \text { to } 0.46)^{*}$ & $0.55(0.48 \text { to } 0.62)^{*}$ \\
\hline & South South & $1.58(1.24 \text { to } 2.02)^{*}$ & $0.49(0.43 \text { to } 0.56)^{\star}$ & $0.68(0.61 \text { to } 0.75)^{\star}$ \\
\hline & South West & $1.41(1.08 \text { to } 1.83)^{*}$ & 0.94 (0.84 to 1.05$)$ & $1.06(0.95$ to 1.17$)$ \\
\hline \multirow[t]{2}{*}{ Residence } & Urban & Reference & & \\
\hline & Rural & $0.97(0.83$ to 1.14$)$ & $0.8(0.73 \text { to } 0.88)^{*}$ & $0.83(0.76 \text { to } 0.90)^{*}$ \\
\hline \multirow{3}{*}{ Wealth index } & Poorest & Reference & & \\
\hline & Middle & $1.41(1.01 \text { to } 1.97)^{*}$ & $1.72(1.47 \text { to } 2.02)^{\star}$ & $1.71(1.49 \text { to } 1.98)^{*}$ \\
\hline & Richest & $1.84(1.33 \text { to } 2.54)^{*}$ & $2.32(1.98 \text { to } 2.71)^{\star}$ & $2.19(1.90 \text { to } 2.53)^{*}$ \\
\hline \multirow[t]{4}{*}{ Highest education } & No education & Reference & & \\
\hline & Primary & $2.88(1.03 \text { to } 8.03)^{*}$ & $3.17(2.69 \text { to } 3.74)^{\star}$ & $3.29(2.80 \text { to } 3.87)^{*}$ \\
\hline & Secondary & $4.47(1.66 \text { to } 12.1)^{*}$ & $4.46(3.76 \text { to } 5.29)^{\star}$ & $4.90(4.16 \text { to } 5.78)^{*}$ \\
\hline & Higher & $5.46(2.00 \text { to } 14.9)^{*}$ & $5.57(4.59 \text { to } 6.76)^{\star}$ & $6.18(5.15 \text { to } 7.42)^{*}$ \\
\hline \multirow[t]{4}{*}{ Religion } & Catholic & Reference & & \\
\hline & Other Xtian & $0.95(0.79$ to 1.15$)$ & $0.93(0.82$ to 1.05$)$ & $0.94(0.85$ to 1.05$)$ \\
\hline & Islam & $1.14(0.83$ to 1.56$)$ & $0.58(0.49 \text { to } 0.67)^{\star}$ & $0.60(0.52 \text { to } 0.69)^{\star}$ \\
\hline & Traditionalist & $0.74(0.10$ to 5.36$)$ & 0.67 (0.39 to 1.15$)$ & 0.67 (0.40 to 1.12$)$ \\
\hline \multirow[t]{4}{*}{ Children ever born } & No birth & Reference & & \\
\hline & 1-2 Births & $0.78(0.65 \text { to } 0.93)^{*}$ & $3.46(2.40 \text { to } 4.99)^{\star}$ & $0.58(0.52 \text { to } 0.65)^{*}$ \\
\hline & 3-4 Births & $0.49(0.23$ to 1.04$)$ & $3.58(2.48 \text { to } 5.17)^{\star}$ & $0.60(0.53 \text { to } 0.68)^{*}$ \\
\hline & $>4$ Births & 0.48 (0.07 to 3.56$)$ & $3.40(2.35 \text { to } 4.93)^{\star}$ & $0.60(0.52 \text { to } 0.68)^{*}$ \\
\hline
\end{tabular}

${ }^{*}$ Significant at $5 \% \mathrm{p}$ value; treated as a continuous variable.

aHR, adjusted HR.

safer sexual practices among adolescents and young adults, the family planning component did not receive much attention. ${ }^{35}$ The programme was neglected, largely owing to the concern of the government about fears expressed by parents/guardian and religious leaders that early introduction of family planning to youth might encourage sexual activity. ${ }^{35}$ In some developed countries, young people have unhindered access to modern contraception and this has helped to avert the consequences of unplanned pregnancy and sexually transmitted infections. ${ }^{36}$ There are no specialised centres owned by the Nigerian government where young people can access modern contraception freely. ${ }^{37}$ Rather, only a few non-governmental organisations have youth centres in some states which offer this service. It is therefore important for policy makers to design culturally sensitive interventions that will promote access to effective modern contraception and potentially reduce the unmet need of family planning in this critical 'lag period'.
Our findings have some limitations. The NDHS data cannot entirely replace the census and thus, there might still be some variations in the observed response. The question about the age of sexual initiation is prone to recall bias and sometimes, the information provided may not be truthful. There is concern that the question about sexual initiation might be emotive and might not elicit a true response. This is why some developed countries have separated a sexual health survey from a survey of other reproductive health. ${ }^{38} 39$ In addition, they also adopted alternative techniques such as audio computerassisted self-interview or other self-administered methods to maintain privacy and confidence about sexual activity questions. $^{38}$ It would also have been useful to analyse the role of respondents' sexual partners in the uptake of contraception.

Despite all these limitations, this study has a significant message for family planning policy and programming in Nigeria. First, the analysis clearly showed that a large proportion of women in Nigeria are not using an 
effective contraceptive method during their early sexual life-a period when sexual adventure and permissiveness is common, with attendant health, social and psychological problems. ${ }^{40}{ }^{41}$ Second, the regional variations and other relevant factors will assist policy makers in identifying gaps in current family planning programmes and also guide development partners to identify critical groups within those who are sexually active group for their interventions.

\section{CONCLUSIONS}

This study shows that modern contraceptive uptake among the sexually active population of women in Nigeria is very low and there is a large period of time in which they engage in unprotected sex, often resulting in unwanted pregnancies and, in some cases, possible health risks. This gap urgently needs a proactive policy and intervention to deal with this worrying observation. An acceptable uptake of modern contraceptives requires enormous, multisectoral and well-coordinated efforts to promote and educate sexually active women with their partners on the proper use of effective modern contraceptives.

Acknowledgements We acknowledge the National Population Commission (Nigeria) and ICF International for granting us access to this data. We acknowledge the technical support received from the Consortium for Advanced Research Training in Africa (CARTA). AFF is a CARTA fellow and he received training in research conception and manuscript writing.

Contributors AFF conceived and designed the study, analysed and wrote the results, contributed to writing the introduction and methodology. ASA, IOM-B contributed to the study design, data analysis, writing the introduction and methodology. All authors proofread the final version of the manuscript.

Funding This research received no grant from any funding agency in the public, commercial or not-for-profit sectors.

Competing interests None declared.

Ethics approval Nigeria National Health research ethics committee.

Provenance and peer review Not commissioned; externally peer reviewed.

Data sharing statement No additional data are available.

Open Access This is an Open Access article distributed in accordance with the Creative Commons Attribution Non Commercial (CC BY-NC 4.0) license, which permits others to distribute, remix, adapt, build upon this work noncommercially, and license their derivative works on different terms, provided the original work is properly cited and the use is non-commercial. See: http:// creativecommons.org/licenses/by-nc/4.0/

\section{REFERENCES}

1. Cleand J, Bernstein S, Ezeh A, et al. Family planning : the unfinished agenda. Lancet 2006;368:1810-27.

2. Adebowale SA, Fagbamigbe FA, Bamgboye EA. Contraceptive use: implication for completed fertility, parity progression and maternal nutritional status in Nigeria. Afr J Reprod Health 2011;15:60-7. http://www.ncbi.nlm.nih.gov/pubmed/22571107

3. Fagbamigbe AF, Adebowale AS, Olaniyan FA. A Comparative analysis of condom use among unmarried youths in rural community in Nigeria. J Public Health Res 2011;1:8-16.

4. Population Reference Bureau. The World's Women and Girls 2012 Datasheet. 2012. http://www.prb.org/pdf11/world-women-girls320770-data-sheet.pdf
5. Lawani LO, Onyebuchi AK, lyoke CA. Dual method use for protection of pregnancy and disease prevention among HIV-infected women in South East Nigeria. BMC Womens Health 2014;14:39.

6. Cohen B. The emerging fertility transition in sub-Saharan Africa. World Dev 1998;26:1431-61.

7. National Population Commission (Nigeria) and ICF International Nigeria Demographic and Health Survey 2013. Abuja, Nigeria: National Population Commission of Nigeria, 2014.

8. United Nations Population Fund. State of the World Population 2004 The Cairo Consensus at ten: population, reproductive health and the global effort to end poverty. New York: UNFPA, 2004.

9. Hubacher D, Mavranezouli I, McGinn E. Unintended pregnancy in sub-Saharan Africa: magnitude of the problem and potential role of contraception implants to alleviate it. Contraception 2008;78:73-8.

10. National Population Commission (Nigeria) and ICF International. Nigeria Demographic and Health Survey, 2008. Abuja, Nigeria: DHS Measure Macro, New York and Nigeria Population Commission, 2009

11. Population Reference Bureau. World Population Data Sheet 2014. US, 2014. http://www.prb.org/pdf14/2014-world-population-datasheet_eng.pdf

12. NPC. Nigeria Over 167 Million. 2013. http://www.population.gov.ng/ index.php/84-news/latest/106-nigeria-over-167-million-populationimplications-and-challenges

13. Federal Ministry of Health N. National policy on population for development, unity, progress and self-reliance. Lagos, Nigeria Federal Ministry of Health, Nigeria, 1988.

14. Federal Ministry of Health N. National policy on population for development, unity, progress and self-reliance. Lagos, Nigeria: Federal Ministry of Health, Nigeria, 2004.

15. Sarkar P. Determinants of age at first birth in Bangladesh. J Mod Math Stat 2010;4:1-6.

16. Bearinger LH, Sieving R, Ferguson J, et al. Global perspectives on the sexual and reproductive health of adolescents: patterns, prevention and potential. Lancet 2007;369:1220-31.

17. Hahm HC, Lee J, Rough K, et al. Gender power control, sexual experiences, safer sex practices and potential HIV risk behaviors among young Asian-American women. AIDS Behav 2012;16:179-88.

18. Lloyd C. Growing up global: the changing transitions to adulthood in developing countries. Washington DC: National Academic Press, 2005.

19. World Bank. Developing and the next generation, World Development Report. Washington DC: International Bank for Reconstruction and Development, 2007.

20. Reynolds H, Jonowitz B, Homan R, et al. Cost-effectiveness of two interventions to prevent HIV-positive births. International AIDS Conference; Bangkok, Thailand, 2004.

21. FMoH. National HIVIAIDS and Reproductive Health and Serological Survey, 2012 (NARHS Plus). Abuja, Nigeria: Federal Ministry of Health, 2013.

22. Austin A. Unmet contraceptive need among married Nigerian women: an examination of trends and drivers. Contraception 2015;91:31-8.

23. OlaOlorun F, Hindin M. Having a say matters: influence of decisionmaking power on contraceptive use among Nigerian women ages 35-49 years. PLOS ONE 2014;9:e98702.

24. Doctor H, Findley S, Afenyadu G, et al. Awareness, use and unmet need for family planning in rural northern Nigeria. Afr J Reprod Heal 2013;17:107-17.

25. Aremu O. The influence of socioeconomic status on women's preferences for modern contraceptive providers in Nigeria: a multilevel choice modeling. Patient Prefer Adherence 2013;7:1213-20.

26. Cleland J, Harbison S, Shah IH. Unmet need for contraception issues and challenges. Stud Fam Plann 2014;45:105-22.

27. Barden-O'Fallon J, Tsui A, Adewuyi A. Social and proximate determinants of sexual activity in rural Nigeria. J Biosoc Sci 2003;35:585-99.

28. Izugbara C, Ibisomi L, Ezeh A, et al. Gendered interests and poor spousal contraceptive communication in Islamic northern Nigeria. J Fam Plann Reprod Heal Care 2010;36:219-24.

29. Avong $\mathrm{H}$. Perception of and attitudes toward the Nigerian federa population policy, family planning program and family planning in Kaduna State, Nigeria. Afr J Reprod Heal 2000;4:66-76.

30. Cleland J, Ali M, Shah I. Trends in protective behaviour among single vs. married young women in sub-Saharan Africa: the big picture. Reprod Health Matters 2006;14:17-22.

31. Wall B. Conflict and compromise: Catholic and public hospital partnerships. Nurs Hist Rev 2010;18:100-17.

32. LeMaire $\mathbf{W}$. The Catholic medical practitioner, family planning and the church. J Fam Plann Reprod Heal Care 2014;41:24-6. 
33. Dienye P, Judah F, Ndukwu G. Frequency of symptoms and health seeking behaviours of menopausal women in an out-patient clinic in Port Harcourt, Nigeria. Glob J Heal Sci 2013;5:39-47.

34. Adedokun B, Morhason-Bello I, Okonkwo S, et al. Sexual activity and urological morbidities among nigerian menopausal women: findings from a community based survey. Ann Med Heal Sci Res 2014;4:206-9.

35. Rosey J, Murray N, Moreland S. Sexuality education in schools: the international experience and implication for Nigeria. Policy Work Pap Ser 2 2004:1-10. http://www.policyproject.com/pubs/workingpapers/ wps-12.pdf (accessed 16 Aug 2015).

36. Gold R, Sonfield A, Richards C, et al. Next steps for America's family planning program: leveraging the potential of Medicaid and title $X$ in an evolving health care system. 2009. http://www. guttmacher.org/pubs/NextSteps.pdf (accessed 16 Aug 2015).
37. Bryant-Comstock K. The road ahead for young people and family planning: costed implementation plan. 2015. http://pai.org/wpcontent/uploads/2015/08/CIP-report-FINAL.2.pdf (accessed 16 Aug 2015).

38. Sexual behaviour documentation in United States. 2009. http:// www.cdc.gov/nchs/nhanes/nhanes2009-2010/SXQ_F. $\mathrm{htm} \#$ SXD021

39. Sexual attitudes and lifestyles in Britain: highlights from Natsal-3. 2014. http://www.natsal.ac.uk/media/823260/natsal_findings_final. pdf

40. Abiodun O, Balogun O. Sexual activity and contraceptive use among young female students of tertiary educational institutions in Ilorin, Nigeria. Contraception 2009;79:146-9.

41. Olley B. Social and health behaviors in youth of the streets of Ibadan, Nigeria. Child Abus Negl 2006;30:271-82. 